\title{
Factors Affecting Teachers Job Satisfaction in Case of Wachemo University
}

\author{
Sewagegn Mola Melaku ${ }^{1} \&$ Tigist Shiferaw Hunde ${ }^{1}$ \\ ${ }^{1}$ Collage of Social Science and Humanities Department of Psychology, Wachemo University, Hossana, Ethiopia \\ Correspondence: Sewagegn Mola Melaku, Collage of Social Science and Humanities Department of Psychology, \\ Wachemo University, Hossana, Ethiopia.
}

Received: April 4, 2020

doi:10.5539/ijps.v12n3p28
Accepted: August 18, 2020

Online Published: August 21, 2020

\begin{abstract}
This study was design to assess factors that affect teachers' job satisfaction in Wachemo University. To meet this objective, the researcher drew 768 in teachers in male are 663 and the rest of female are 105 in number. In order to make the study the researcher was select 54 males and 34 female's teachers to determine sample size by using simple random sampling method. The main objective of this study was to assess and explore the factors that contribute to job satisfaction. The basic research question of this paper was first, what factors affect the teachers' job satisfaction in working place second, what is negative the job satisfaction of teachers in working place Third, what mechanism are helps to reduce the existence of specific factors. So, the data collected is through questionnaire and interview. Finally, the collected data were analyzed by using table and percentage. The result revealed that the major work related factors that affect teachers' job satisfaction were salary stressful job, overtime work without payment, relationship with top management opportunities for advancement, chance for promotion, and availability of teaching learning materials and rules and regulation of the campus. The study suggested that it is advisable to the concerned bodies especially the management organ of Wachemo University should give on attention to those factors and should plan different strategies to improve teachers' job satisfaction and there must be motivational and incentive strategies to strengthen and motivated teachers and to bring job satisfaction.
\end{abstract}

Keywords: teachers, job satisfaction and factors

\section{Introduction}

Education is one of the key instrument and element in building developing societies and our future civilization. It is a process by which man transmits his experiences, new findings, and values accumulated over the years in his struggle for survival and development, through generations (Ministry of education, 1999). In Addition, Education enable individuals and society to make all rounded participation in the development process by acquiring knowledge, ability, skill and attitudes in the in the society. It is also a guide for cultural, political, social and economic developing citizens to cope with the intellectual, conceptual and attitudinal global change (Harmer, C., \& Smith, F., 1978).

Education has been one of the important institutions in all societies from the human history. It has played important role in moving countries for world Teachers are indeed the pivot on which the world education revolve and are entrusted with the mental, physical and moral upbringing of students in all education institutions in the world (Paula, M., 1996).

Teachers play the most important role in the education process. Through this education they improve and develop the human mind. Moreover, teachers are the focal person to achieve and implement the Ethiopia's educational objective and goals. So, to achieve the educational objectives effectively, it is essential to keep motivated teachers are in their performance. For complete utilization of teachers, efforts and potential, the must respect their profession and they should be satisfied with it (Ministry of education, 1999).

In Ethiopia, motivation of teachers in performing their tasks and work is highly affected. Most teachers in the country could not fulfill much of their basic needs. Beyond this, their social status, recognition, advancement and acceptance by the community has deteriorated, many teacher are de-motivated and unsatisfactory in performing their work properly as well as they ready to leave their professional as they get an opportunity and for better 
salary. According to Thomas, S. (1967) salary and social status, lack of reward and recognition by the school community and society, school mal-administration and classroom interaction with their students have negative impact on teacher's job satisfaction in a work place. Generally, we can say that collage can achieve their objectives if they have more motivated teachers than anything else. Similarly, Thomas S. (1967) states that less motivated teachers is likely to perform their expected duties less satisfactorily. Because of by any means, most teachers are ready to leave their job at any possible time; this may lead to a loss of achieving the collages' educational objectives. Therefore, the education organizations and collage system should have great attention in motivating teachers for a better performance and in achieving the expected educational goals and objectives for the future development of the country.

The country paying a greater attention to their higher education bringing structural and technological reforms, efficiently utilization their intellectual resources consistency to the need high education are now the leading giants in the global world. A country which has been equipped and highly facilitated with quality institution, enriched with creative, talented pool of academic staff, will definitely be the market leader in innovations. So, to have that particular aspect of quality institution enriched with creative, talented academic staff, job satisfaction among academic staff. Therefore, those various dimensions should be contributes highly in productively and performance of individual so as to the organization (Ministry of education, 1999).

Job satisfaction is the collection of a work's feeling in relation to the nature and condition of workers might be satisfied with some part of their job while simultaneously dissatisfied with other. Job satisfaction refers to the extent of need fulfillment of employees, which provides basis for organizational assessment and evaluation. Therefore, effectiveness is highly recommended in all stages of employees' compensation and success planning. The decreased satisfaction and lack of commitment bring inefficiency and loses in teachers and students (Harmer, C., \& Smith, F., 1978).

According to Locker, E. (1976) satisfaction comes through the fulfillment of various needs such as food, health, safety and other social needs as the result of performed task. The measures help in satisfaction assessment include pay, career stability, sense of pride with institute and its belongingness to local customs and tradition other factors life style, pay, works environment and supervision. The satisfied worker have a very constructive attitude about work and adversely. Dissatisfied staff workers has destructive and negative toward work. The attitude shift corresponds to a complex placement of behavioral cognition, emotions, behavioral tendencies and overall working style. On the other hand, Lawler, A. (1976) On job satisfaction factors are related to the work itself such as feeling of dependence, feeling of achievement, feeling of victory, feeling of self-esteem, feeling of control and other similar feeling obtained from works, Whereas external satisfactory factor are not directly related to work itself such as good relationship with colleagues, high salary, good welfare and utilities. So, the influence on job satisfaction can be divided into work related and employee related factors.

The focus of this study is on factors contributing to overall job satisfaction for teachers. There are so many factors that contribute to job satisfaction such as: additional support and leadership, student behavior, positive school atmosphere and teacher autonomy (Perier, M., and Baker, P., 1997). Our country Ethiopia is part of the world there are around 33 higher educational organizations. From those higher educational organizations Wachemo University is one of the new emerged universities in 2003 E.C in southern Nation Nationality and people's region. In compared to other institutions Wachemo University those are low skills, lack of language, lack of motivation, lack of rewards, unsuitable working condition and unclear organization rule and policies, lack of promotion and recognition lack of awareness those are influence job satisfaction. This study will be conduct by assessing factors of teacher's job satisfaction in Wachemo University.

Job satisfaction is widely studied across many academic disciplines, including psychology, sociology, economic, and the management science (Judge, L., \& Durham, C., 1997). So, research has shown that satisfied employees are more productive, deliver higher quality of work and improve a firm's competitiveness and success. Similarly, according to Judge, L. and Durham, C. (1997), Job satisfaction is generally recognized as multi-faceted construct that includes employee feeling about a variety of both intrinsic that is the job itself and opportunity for personal growth and accomplishment and extrinsic, which includes pay and benefits, company policies, super vision and support, co-workers, job security, changes for promotion. The contrary is the case with some teacher in university as a lot of negative work behavior such as lateness, absenteeism, lack of real in carrying out assigned tasks, sneaking out of universities to run private business, trading in the school premise as exhibited by them on daily basis. This hole some attitude to work seems to suggest that these teachers are greatly dissatisfied with their job (Locker, E., 1976). 
Job satisfaction in industrial and educational organization and states that level of satisfaction in teaching depends up on teachers expectation and whether or not they were fulfilled previous studies concerning job satisfaction have identifies certain factors influencing job satisfaction, recognition for achievement, work itself less of salary, achievement and responsibility and advancement, lack of teaching experience, lack of language communication skill and nature of work, level of education and operating conditions (Bennell, P., \& Akyeampong, K., 2007). Moreover, motivated and satisfied workers not perform better but also provide better service to customers which could result in improving customers (students) satisfaction. Employee satisfaction is associated with positive employee behavior. In addition, job satisfaction is also directly related to increment or decreasing of salary of workers. Employee pay satisfaction usually influences their job satisfaction. For this to happen, their needs should be fulfilled so that they could be motivated, otherwise they could not be encouraged enough to carry out their responsibilities (Lawler, A., 1976). In Addition to this, some conducted in Ethiopia by researchers indicate that there is no work satisfaction in most territory. Among this in Wachemo University there are factors that lead to job dissatisfaction. Therefore, this study was aimed to identify the main factors that affecting teachers' job satisfaction in case of Wachemo University was guided by the following research questions.

1. What factors affect the teachers' job satisfaction in working place?

2. What is negative the job satisfaction of teachers in working place?

3. What mechanism are helps to reduce the existence of specific factors?

The main purpose of the study is to exploring the major factors that affecting teacher's job satisfaction. Specifically, to assess and explore the major factors that affect teacher's job satisfaction in working placing, to assess the impact of factors that affect teacher's job satisfaction on the overall job satisfaction and to suggest possible mechanism that helps to reduce the existences of negative factors that result in decreased job satisfaction.

\section{Methodology}

In order to achieve the objective of the study the researcher used descriptive methods. Because it helps the research describes factors affecting teacher's job satisfaction. The target populations of this were all teachers of Wachemo University they are in work. They are 768 in teachers in male are 663 and the rest of female are 105 in number. The researcher had taken sample from the target population by using simple random sampling method. In order to make the study and to accomplish objective of the study successfully the researcher was select from this study are 54 males and 34 females are selected to totally teachers to determine sample size.

The research uses Yemane, T. (1967), take 8.68\% of teachers.

$$
\begin{aligned}
& \eta=\frac{M}{1+W\left(e^{2}\right.} \\
& \text { n: sample size } \\
& \text { N: total population } \\
& \text { E: error }
\end{aligned}
$$

The researcher used sample random sampling techniques. Because of the target population of the study have different common characteristics. First the researches makes a strata using their common characteristics and select a sample from male and females teacher sampling techniques specially by using lottery methods. In order to gather important information for the study, questionnaire, and interview was employed. For the purpose of getting data of various types, the questionnaires include both open-ended and closed-ended questions. The data collection procedure is first the researcher asks co operational letter from Wachemo university department of psychology. Then, forward to the concerned body. The researchers were direct the participant as to how to fill the questionnaire and the researcher administer the questionnaire to the sample population and after specific time questionnaires are distribute to the sample population. After the collection of the data the result was analysis carefully in order to keep the research valid, reliable, and accurate. In analyzing the data first researcher categorize and coded the response of the participation then, by using both qualitative and quantitative techniques the data was analyzed and interpreted. 


\section{Results}

Table 1. Background information of the respondents

\begin{tabular}{llll}
\hline Characteristics & Alternative & \multicolumn{2}{c}{ Respondents } \\
Sex & & Numbers & $\%$ \\
& Male & 54 & 61.36 \\
& Female & 34 & 38.34 \\
& Total & 100 \\
Age & $20-30$ & 88 & 38.34 \\
& $31-40$ & 34 & 50 \\
& $41-50$ & 44 & 11.36 \\
& $51-60$ & 10 & 0 \\
\hline Qualification & $>60$ & 0 & 0 \\
& Total & 0 & 100 \\
& Bachelor & 88 & 28.41 \\
& Master & 25 & 63.64 \\
\hline
\end{tabular}

Table 1 indicates that from the total 88 participants 54(61.36\%) of the respondent were males and the remaining $34(38.34 \%)$ of the respondents were females. With regarding to their age $34(38.34 \%)$ of the respondents were 20-30 years. $44(50 \%)$ of the respondents were $31-40$ years and $10(11.36 \%)$ of the respondents were $41-50$ years old. With regarding to their qualification $25(28.41 \%)$ of the respondent have bachelor. 56(63.64\%) of the respondent have master and 7(7.95\%) of the respondent have $\mathrm{PhD}$.

Table 2. Work experiences of the respondents

\begin{tabular}{llll}
\hline & Alternatives & \multicolumn{2}{l}{ Respondents } \\
\cline { 3 - 4 } $\begin{array}{l}\text { Description } \\
\text { How long have you been in }\end{array}$ & Number & $\%$ \\
teaching? & & 46 & 52.27 \\
& & 32 & 36.36 \\
& & 10 & 11.36 \\
& & 0 & 0 \\
& & 0 & 0 \\
& & 0 & 100 \\
\end{tabular}

As table 2 shows that work experience of the respondents, 46(52.27\%) of the respondents have 1-5 years' work experience, $32(36.36 \%)$ of the respondents have 6-10 years' experience and $10(11.36 \%)$ of the respondents have 11-15 years' work experience. 
Table 3. Teachers' job satisfaction factor linkage with their profession relationship with top management, co-workers and students

\begin{tabular}{|c|c|c|c|}
\hline \multirow[t]{2}{*}{ Characteristics } & \multirow[t]{2}{*}{ Alternatives } & \multicolumn{2}{|c|}{ Respondents } \\
\hline & & Number & $\%$ \\
\hline \multirow[t]{3}{*}{ Do you love your profession? } & Yes & 84 & 95.45 \\
\hline & No & 4 & 4.55 \\
\hline & Total & 88 & 100 \\
\hline \multirow[t]{3}{*}{$\begin{array}{l}\text { Do you have good relationship } \\
\text { with top management? }\end{array}$} & Yes & 46 & 52.27 \\
\hline & No & 42 & 47.73 \\
\hline & Total & 88 & 100 \\
\hline \multirow{3}{*}{$\begin{array}{l}\text { Do you good relationship with } \\
\text { coworkers? }\end{array}$} & YES & 80 & 90.91 \\
\hline & No & 8 & 909 \\
\hline & Total & 88 & 100 \\
\hline \multirow[t]{3}{*}{$\begin{array}{l}\text { Do you have good relationship } \\
\text { with students? }\end{array}$} & YES & 85 & 96.59 \\
\hline & NO & 3 & 3.41 \\
\hline & Total & 88 & 100 \\
\hline
\end{tabular}

As table 3 shows that $84(95.45 \%)$ of the respondents love their profession (job) conversely $4(4.55 \%)$ of the respondents do not love their profession job.

Regarding to relationship with top managements $46(52.27 \%)$ of the respondents have good relationship with their top management $42(47.72 \%)$ of the respondents have no good relationship with their managements. This reason why most of the respondents have no good relationship with to managements was the managers are not capable of handling the staff. The university does not create a conductive environment for teachers and top managers to develop good relationship among themselves, they have no good faith and academic quality for the improvement of teaching learning process, they always act as a both that attempt to everything in their subordinates.

Regarding to relationship with co-workers $80(90.91 \%)$ of the respondents have good relationship with co-workers and $8(9.09 \%)$ of the respondents have no good relationship with co-workers because some workers are so selfish and they are not truthful for their co-workers and for their jobs. Concerning relationship with students $85(95.59 \%)$ the respondents have good relationship with their 3(3.41\%) of the respondents has good relationship with students. Some respondents believe that students have lack of respect for and some they are not come on time to the class.

Table 4. Teachers' perceived reason towards work related factors as to how they influence their job satisfaction

\begin{tabular}{|c|c|c|c|}
\hline \multirow[t]{2}{*}{ Description } & \multirow[t]{2}{*}{ Alternatives } & \multicolumn{2}{|c|}{ Respondents } \\
\hline & & Numbers & $\%$ \\
\hline \multirow[t]{3}{*}{ Are satisfied with you pay? } & Yes & 58 & 65.91 \\
\hline & No & 30 & 34.09 \\
\hline & Total & 88 & 100 \\
\hline \multirow{3}{*}{$\begin{array}{l}\text { Do you work an overtime work } \\
\text { without payments? }\end{array}$} & Yes & 17 & 19.32 \\
\hline & No & 71 & 80.68 \\
\hline & Total & 88 & 100 \\
\hline \multirow{3}{*}{$\begin{array}{l}\text { Do get enough facility in your } \\
\text { work place? }\end{array}$} & Yes & 8 & 9.09 \\
\hline & No & 80 & 90.91 \\
\hline & Total & 88 & 100 \\
\hline
\end{tabular}


Table 4 indicates that 58(65.91\%) of the respondents are satisfied with their pay (salary) and 30(34.09\%) of the respondents are not satisfied with their pay (salary). The reason behind the dissatisfaction of teachers with their pay as it is stated by the majority of the respondents' payment was not enough to cover current living expense, the work load and time is always increasing but the monthly salary was decreasing. The country has no economic process to pay attractive salary and some have no critical attention to the profession. The payment of teacher and other profession are not matching equal because of this some people think that teaching is weak profession and finally they suggested that the payments is percent of money for different case and they live their need rather a to their pockets. Regarding to an overtime work without payment $17(19.09 \%)$ of the respondents had worked an overtime work without payment and $71(80.68 \%)$ of the respondent did not work an overtime work at all. Concerning to enough facility in the work place $8(9.09 \%)$ of the respondent can get enough facilities in their worker place but $80(90.91 \%)$ of the respondents were not getting enough facility in their working place.

With regard to the feeling that teachers feel while they are in teaching. Some of the respondents suggested that feel good while they are in teaching. The reason behind their feeling was they feeling was they believe that teaching was a great profession and they consider themselves as a very important person who gives his/her whole life to shape others mind and make them good generation to the future who will lead their country, others suggested that they that since teaching is my choice and I am happy so to the teacher but sometime am worried about students future job employer.

Some of the respondents also suggested that they feel bad while they are in teaching. Their feeling depends on the students. If the students are active participation they feel relaxed and motivated to teach but if the students are shy and quite they feel bad.

Table 5. Level of teachers' job satisfaction

\begin{tabular}{llllll}
\hline Description & & Alternative & \multicolumn{2}{c}{ Respondents } \\
\cline { 3 - 4 } $\begin{array}{l}\text { How do you } \\
\text { satisfaction? }\end{array}$ & & rate you job & Excellent & Number & $\%$ \\
& & Very good & 7 & 7.95 \\
& & Good & 15 & 17.05 \\
& & Fair & 45 & 51.14 \\
& Poor & 15 & 17.05 \\
& & Total & 6 & 6.82 \\
\hline
\end{tabular}

Table 5 indicates that 7(7.95\%) of the respondents rate their job satisfaction as excellent, $15(17.05 \%)$ of the respondents rate their job satisfaction very good, 45(51.14\%) of the respondents rate their job satisfaction as good and $15(17.05 \%)$ and $6(6.82 \%)$ of the respondents rate their job satisfaction as fair and poor respectively. The reason why some teacher rate their job satisfaction as fair and poor was the working environments was not conducive, the governance in this university is not good and enough to be satisfied and even the salary and other benefits are not existed. The students poor performance, poor infrastructure, the relationship between teachers and managers was poor and also the teacher condition was not conducive were some of the reason that have been mentioned. 
Table 6. Work related factors that affect teacher's job satisfaction

\begin{tabular}{|c|c|c|c|c|c|c|c|c|c|c|c|c|}
\hline \multirow[t]{2}{*}{ Factors } & \multicolumn{2}{|c|}{$\begin{array}{l}\text { Strongly } \\
\text { Agree }\end{array}$} & \multicolumn{2}{|c|}{ Agree } & \multicolumn{2}{|c|}{ Neither } & \multicolumn{2}{|c|}{ Disagree } & \multicolumn{2}{|c|}{$\begin{array}{l}\text { Strongly } \\
\text { Disagree }\end{array}$} & \multicolumn{2}{|c|}{ Total } \\
\hline & No & $\%$ & No & $\%$ & No & $\%$ & No & $\%$ & No & $\%$ & No & $\%$ \\
\hline Payment & 35 & 39.77 & 27 & 30.68 & 18 & 20.45 & 0 & 0 & 8 & 9.09 & 88 & 100 \\
\hline Stressful job & 6 & 6.82 & 28 & 31.82 & 28 & 31.82 & 17 & 19.32 & 9 & 10.23 & 88 & 100 \\
\hline $\begin{array}{l}\text { Overtime } \\
\text { work without } \\
\text { payment }\end{array}$ & 8 & 9.09 & 17 & 19.32 & 0 & 0 & 38 & 43.18 & 25 & 28.14 & 88 & 100 \\
\hline $\begin{array}{l}\text { Selfish and } \\
\text { uncomprising } \\
\text { colleagues }\end{array}$ & 24 & 27.27 & 20 & 22.73 & 14 & 15.91 & 22 & 25 & 7 & 7.98 & 88 & 100 \\
\hline $\begin{array}{l}\text { Relationship } \\
\text { With top } \\
\text { Management }\end{array}$ & 20 & 22.73 & 20 & 22.73 & 0 & 0 & 20 & 22.73 & 26 & 29.55 & 88 & 100 \\
\hline $\begin{array}{l}\text { Opportunity } \\
\text { for } \\
\text { Advancement }\end{array}$ & 25 & 28.41 & 25 & 28.41 & 18 & 20.45 & 8 & 9.09 & 10 & 11.36 & 88 & 100 \\
\hline $\begin{array}{l}\text { Chance for } \\
\text { promotion }\end{array}$ & 20 & 22.73 & 27 & 30.68 & 17 & 19.32 & 9 & 10.23 & 16 & 18.18 & 88 & 100 \\
\hline $\begin{array}{l}\text { Availability of } \\
\text { teaching } \\
\text { learning } \\
\text { materials }\end{array}$ & 22 & 25 & 26 & 29.55 & 22 & 25 & 8 & 9.09 & 10 & 11.36 & 88 & 100 \\
\hline $\begin{array}{l}\text { Rules and } \\
\text { Regulation of } \\
\text { the campus }\end{array}$ & 18 & 20.45 & 26 & 29.55 & 26 & 29.55 & 8 & 9.09 & 10 & 11.36 & 88 & 100 \\
\hline
\end{tabular}

Table 6 indicates that $35(39.77 \%$ ) of the respondents strongly agree that payment was a major factors that affect teachers job satisfaction while the rest $27(30.68 \%)$ and $18(20.45 \%)$ of the respondents agree and strongly agree that payment was a factors that teachers' teachers job satisfaction respectively. They result revealed that $6(6.82 \%)$ of the respondents had also agreed that stressful job affect job. Job satisfaction of teacher while the remaining respondent 28(31.82\%), 17(19.82\%), 9(10.23\%) had responded neutral, disagree, strongly disagree respectively. With regard to the factor overtime work without payment majority of the respondent I.e. 8(9.09\%) had strongly agreed. However, $25(28.41 \%)$ of the respondents had also strongly disagreed that overtime work without payment was a major factor that teacher job satisfaction.

Concerning of the factor selfish and uncompromising colleagues 24(227.27\%), 20(22.73\%) and 14(15.91\%) of the respondents had responded strongly agree, agree and neutral respectively. Meanwhile $7(7.95 \%)$ of the respondents and had strongly disagreed the factors as major factors that affect teachers' satisfaction. In the case of the factors relationship with top management most of the respondents' i.e. $20(22.73 \%)$ and strongly agreed and $20(22.73 \%$ ) of the respondent had agreed the idea that relationship with top management was a major factor that affect the teachers' job satisfaction.

Concerning the factor opportunities for advancement majority of the respondents i.e. $25(29.41 \%)$ has strongly and $25(29.41 \%$ ) of the respondent had also agreed that an opportunity for advancement was major factors that affect teachers' job satisfaction. The result also depicted that majority i.e. $20(22.73 \%)$ and $27(30.68 \%)$ of the respondents had strongly agree and agree respectively. To the factor that chance for promotion was major factors that affect teacher job satisfaction. Yet concerning that factor availability of teaching and learning materials most of the respondents' i.e. $22(25 \%)$ had agreed with the factor as major factor that affect teachers' job satisfaction. Similarly concerning the factor rules and regulation of the campus most of the respondents i.e. 18 and 26 had 
strongly agree and agree respectively to the idea as a major factor that affect teachers' job satisfaction. Note all information regarding major work related factor that affect teachers' job satisfaction are presented in detail in table above.

As the result obtained from the qualitative data revealed most of the teachers recommended that to improve teachers' job satisfaction the management should respect the profession, improve students teacher relationship, re-scaling salary, improving motivational strategies and incentives, there should be good governance transparency of management decision, clearly stated responsibility and accountability, creating welcoming environment, increasing facilities of education, keeping teacher's safety, decreasing work over load, payment for overtime work, increasing chance for scholarship, decreasing the negative attitude of toward the profession, improving infrastructure in the campus, planning open and flexible policies (rules and regulations), awarding staffs with cooperative and positive thinking sprit and finally they recommended that every society of the campus should work for quality of education rather than quantity.

\section{Discussion}

There are many factors that negatively affect teachers' job satisfaction. This study more focus on work related factors that affect teachers' job satisfaction. The result of this show that this work related factors to dissatisfaction on their job. From these factors payment, relationship with top management, opportunities for advancement, chance of promotion, availability of teaching learning materials and rules and regulations of the campus were the major factors create great impacted on the overall quality of education. For smooth teaching learning process job satisfaction is mandatory. To bring satisfaction among teachers these factors that negatively affect job satisfaction should be reduced.

As it had already mentioned in the background of the study, Job satisfaction is the collection of a work's feeling in relation to the nature and condition of workers might be satisfied with some part of their job while simultaneously dissatisfied with other. Job satisfaction refers to the extent of need fulfillment of employees, which provides basis for organizational assessment and evaluation. Therefore, effectiveness is highly recommended in all stages of employees' compensation and success planning. The decreased satisfaction and lack of commitment bring inefficiency and loses in teachers and students (Harmer, C. and Smith, F., 1978).

According to Perier, M. and Baker, P. (1997) job satisfaction is divided is into two: internal and external satisfaction factors. Internal satisfaction factors are feeling of control and the external satisfaction factors relationship with colleagues, salary, good, welfare and unities. They external satisfaction factors are more related with this study finding. No enough salary, no good reface and utilities job satisfaction become decrease. Similarly, According to Thomas, S. (1967), focuses on factors contributing to job satisfaction. For teachers they identified administrative support and leadership, student behavior and performance and Striving to create an atmosphere where teacher have a positive mental and emotional attitude about their job is in the best interest of every one. All the studies emphasize factors that influence job satisfaction. The factors are related each other in all studies.

\section{Conclusions}

The major work related factors that affect teachers' job satisfaction were salary stressful job. Overtime work without payment, relationship with top management opportunities for advancement, chance for promotion, availability of teaching learning materials and rules and regulation of the campus. All these work related factors have negative impact on the teaching learning process. It is better to take a corrective action on those factors that negatively affect teachers' job satisfaction.

\section{Acknowledgement}

We would like to express our gratitude to all who generously gave their time, energy and knowledge in helping us while understanding this research. We would like to thank Wachemo University staffs to give invaluable advices throughout our research work.

Last express my heartfelt thanks to family, particularly my brother and sister for their economic support to accomplish this work.

\section{References}

Bennell, P., \& Akyeampong, K. (2007). Teachers motivation in sub-Saharan Africa and South Asia. Department of international Development Educational papers.

Harmer, C., \& Smith, F. (1978). Wok attitude as prediction of unionization activity.94.319 340. Journal of applied psychology. 
Judge, L., \& Durham, C. (1997). The dispositional case of job satisfaction: Journal of organizational behavior. 19:717127.

Lawler, A. (1976). The Nature and Causes of Job Satisfaction. Book chapter in handbook of industrial and organizational psychology (1960) consulting psychologist's press.

Locker, E. (1976). The nature case job satisfaction: Hand book of industrial organizational psychology (1297-1349). Chicago: Rand Mcnally.

Ministry of education. (1999). Education Statistics Annual Abstract (ESAA).

Paula, M. (1996). The relationship of empowerment to teachers' job commitment job satisfaction. Journal of instructions.

Perier, M., \& Baker, P. (1997). Job satisfaction among American teachers: effect of work.

Thomas, S. (1967). Factors that affect satisfaction and dissatisfaction of teacher.

Yemane, T. (1967). Elementary sampling theory. Engelwood, cliffs, New jersey: Prentice - Hall, Inc, pp x-405.

\section{Copyrights}

Copyright for this article is retained by the author(s), with first publication rights granted to the journal.

This is an open-access article distributed under the terms and conditions of the Creative Commons Attribution license (http://creativecommons.org/licenses/by/4.0/). 